\title{
Training kindergarten and primary education student teachers to plan learning units combining TPACK, LAT and multimodality
}

\author{
L. Messina*, S. Tabone** \\ * University of Padova, Italy \\ ** PhD, University of Padova, Italy
}

\begin{abstract}
This contribution presents an educational proposal, which will be the prelude to an action research project aimed at the operative integration of technologies in the education and training of future kindergarten and primary school teachers. The contribution proposes, in particular, an instrument for planning learning units that has been developed according to specific theoretical models - TPACKTechnological Pedagogical And Content Knowledge (Mishra \& Koehler, 2006), LAT-Learning Activity Types (Harris \& Hofer, 2009), multimodality (Cope \& Kalantzis, 2000) - and can be used in a learning path for the above-mentioned future teachers both as part of courses on educational technology as well as those for specific disciplines. This contribution illustrates and justifies the structure of such an instrument, the use of which could help enable future teachers to develop an integrated planning procedure that should be dynamic and open to refinements and improvements as they meet with different knowledge domains during their training.
\end{abstract}

Keywords: Student teachers' training, TPACK, learning activities types, multimodality, instructional planning

\section{On TPACK and its operationalization}

Research into the integration of technology in education, from kindergarten to higher education, has reached quite notable dimensions, suggesting various study approaches - e.g. case studies, teacher self-reports, descriptions of good practices or experimentations of specific technologies (Lawless \& Pellegrino, 2007) - and developing different models and strategies aimed at integrating technology into teachers' training (Kay, 2006; Tondeur et al., 2012).

However, surveys and research continue to point out that teachers, in general, do not have adequate preparation to profitably integrate technology in educational practices, emphasizing the importance of initial training (Enochson \& Rizza, 2009; Eurydice, 2011).

Among the theoretical models that can guide teachers' training, those that focus on teacher knowledge, developing the PCK-Pedagogical Content Knowledge (Shulman, 1986, 1987), and that are synthesized in TPCK or TPACK acronyms (Angeli \& Valanides, 2005; Mishra \& Koehler 2006; Niess, 2005; Pierson, 2001), seem to be particularly interesting and appropriate for teachers' training and are achieving increasing success (Voogt et al., 2013).

The TPACK proposed by Mishra and Koehler (2006; Koehler \& Mishra, 2008), in particular, is today one of the most popular models (Finger et al., 2013) and has also been adopted by us in some research with in-service teachers, student teachers and Education faculty (Messina \& Tabone, 2011, 2012, 2013, 2014).

The model of Mishra and Koehler contemplates:

- three basic forms of knowledge: Content (CK), Pedagogy (PC), Technology (TK);

- their intersections: Pedagogical Content Knowledge (PCK) - how to teach specific content; Technological Content Knowledge (TCK) - dealing with the best 
technologies to represent particular content; Technological Pedagogical Knowledge (TPK) - how to use specific technologies in teaching;

- their integration in another form of knowledge: Technological Pedagogical And Content Knowledge (TPACK) - how to teach content, using technologies that best represent it in ways that are appropriate to students' characteristics (Koehler \& Mishra, 2008, pp. 17-18).

The TPACK represents the "dynamic and transactional relationship between content, pedagogy and technology" (Koehler et al., 2007, p. 741) and it is a conceptual framework that teachers should master to effectively integrate technology in their present or future classrooms.

Despite the success of TPACK, some limitations have been attributed to it, including the unclear boundaries between the components of the model (Cox \& Graham, 2009; Archambault \& Barnet, 2010), the lack of precise and shared definitions for "new technology" (Grahm, 2011), the "parsimony" of the model, which excludes important personal features, such as teachers' values and beliefs regarding teaching and learning (Angeli \& Valanides, 2009, p. 157), to which we can also add the relevant dimensions of motivation (Cullen \& Greene, 2011) and emotion (Kay, 2008).

What in general emerges from the research is that TPACK is an extremely useful theoretical model to help teachers and student teachers to reflect on possible intersections of content, pedagogy and technology, but one of the problems that it presents lies in how it can be translated by teachers into operative instructional planning and classroom practices.

Several scholars have dealt with how to operationalize the TPACK or TPCK, providing guidance for teachers' training. For example, Koehler and Mishra (2005) propose a training approach, learning by design, that "allows teachers to explore the ill-structured domain of educational technology and develop flexible ways of thinking about technology, design and learning, and thus develop Technological Pedagogical Content Knowledge” (Koehler \& Mishra, 2005, p. 99); Angeli and Valanides suggest a "situative methodology", technology mapping, that enables "teachers to develop complex and interrelated ideas between the affordances of technology and their pedagogical content knowledge" (Angeli \& Valanides, 2013, p. 204); Niess and colleagues, observing mathematics teachers, have developed a model that represents "teacher levels as their thinking and understanding merge toward the interconnected and integrated manner identified by TPACK" (Niess et al., 2009, p. 10); Harris and Hofer (2009) propose an operationalization of TPACK based on activity types, considered as "the building blocks for instructional planning", since "each activity type captures what is most essential about the structure of a particular kind of learning action as it relates to what students do when engaged in that particular learningrelated activity (e.g., 'group discussion'; 'role play'; ‘field-trip')” (Harris \& Hofer, 2009, pp. 100-101).

Harris and Hofer (http://activitytypes.wmwikis.net) have elaborated taxonomies of activity types for different subjects, from literacy to mathematics, physical education, visual arts and so on, and they encourage teachers to plan a lesson or teaching units or a project by: "choosing learning goals; making practical pedagogical decisions about the nature of the learning experience; selecting and sequencing appropriate activity types to combine to form the learning experience; selecting formative and summative assessment strategies that will reveal what and how well students are learning; 
selecting tools and resources that will best help students to benefit from the learning experience being planned” (Harris \& Hofer, 2009, p. 100).

The operationalization proposal of Harris and Hofer (see also Harris et al., 2009), in addition to introducing an extremely relevant element that is often neglected in instructional planning, i.e. specific activities in which teachers intend to engage students, considers another element omitted perhaps more often during planning and equally, if not more, important: the knowledge forms involved in the different activity types, which range from knowledge building to expression of knowledge, being the knowledge convergent or divergent, product- or process-oriented and related both to verbal language as well as to other meaning representation modalities.

Regarding this final aspect, in our opinion the proposal made by Harris and Hofer (2009; Hofer \& Harris, 2010) can be effectively integrated with the theories of Cope and Kalantzis (2000), especially with respect to the multimodal representation of meaning making, which is made possible through various forms of language divided by them into the following categories: written language, oral language, visual representation, audio representation, tactile representation, gestural representation, spatial representation.

In a certain sense, this is also the direction followed by Angeli and Valanides (2009), who consider also the representation modalities that tool affordances make possible, but see them as means to transform a content into representations that can actually foster or augment students' conceptual understanding.

From the point of view of Cope and Kalantzis, multimodal representation, which is at the core of their "pedagogy of multiliteracies" - or simply "literacies" (Kalantzis \& Cope, 2012), brings to mind those particularities that the process of symbolization can assume, given the multimodal environments in which children live. In relation to this process, the different forms of language, together with the respective ways of meaning making, can act as “a kind of cognitive keyboard” (Rivoltella, 2012, p. 139).

This is why we believe that, together with knowledge forms (Harris \& Hofer, 2009), also modalities of knowledge representation have to be contemplated (Cope \& Kalantzis, 2009). Consequently, during their training path and their activities of instructional planning, teachers also need to be trained to consider students' "mental activities", which nowadays are heavily influenced by the multimodal languages of the new technologies in which they are immersed.

\section{An instrument for integrated instructional planning}

Starting from the theoretical assumptions that have just been briefly summarised, and in light of the research we had already carried out (especially Messina \& Tabone, 2013), we have outlined an instrument of training - a grid for instructional planning that is intended to help develop an integrated procedure for the planning of learning units.

This instrument is one of the resources used in an integrated teaching course that consists of two modules - each covering 30 hours of lessons - namely Teaching Methodology and Educational Technology, held by two different professors. Each module is completed by workshop activities of 16 hours, and the Educational Technology module is held by L. Messina, one of the authors of this article, who also supervises the related workshop. 
The teaching course is part of the second year of the single-cycle degree in Primary Education at our university and it is attended by 200 students each year. The Educational Technology module comes immediately after that of Teaching Methodologies and its workshop activities.

The Educational Technology module begins with a presentation of national and international educational policies, together with an introduction to the role of technology as well as to youth culture. After this, a substantial number of lessons are given over to the theoretical approaches that have been mentioned above, in particular PCK (Shulman, 1986, 1987) TPACK (Mishra \& Koehler, 2006), LAT (Harris \& Hofer, 2009), and multimodality (Cope \& Kalantzis, 2000, 2009). Parallel to these lessons, students study the theories concerned and, dividing themselves into groups of 25 to 30 according to the field of experience (in the case of kindergarten) or to the discipline (primary school) they are interested in, they are free to explore the technologies and educational resources fitting their chosen area. They then share the results of their individual explorations in discussion forums on the university's Moodle platform, where the module has a dedicated page. Upon conclusion of the lessons of the module and before the beginning of the related Educational Technology workshop, each group of students uploads onto the platform a list of all the resources they have found, singling out 6 to 8 of these, each of which is evaluated using a series of criteria indicated by us.

In the Educational Technology workshop the groups of students, further subdivided into smaller groups of 5 or 6 students and under the guidance of specially-trained tutors, have to plan a learning unit for one of the two levels of school in question (kindergarten or primary), transforming the theories they have studied into action plans.

For the present academic year, we have given the students an instrument outlined by us for planning a learning unit, i.e. a grid to refer to for the purposes of their planning. This grid is shown below in two separate tables to help visualize the innovations we are proposing. We have left in the Tables 1 and 2 the same numeration as is found in the overall grid used by the students. The grid is also accompanied by a brief legend to remind students of the agreed meaning of the individual elements and, in some cases, the theoretical references that they refer back to.

Table 1. Elements usually considered in instructional planning.

\begin{tabular}{|l|l|l|l|l|l|l|}
\hline 1.Context & $\begin{array}{l}\text { 2.Goals/ } \\
\text { Objectives }\end{array}$ & $\begin{array}{l}\text { 3.Time } \\
\text { schedule }\end{array}$ & $\begin{array}{l}\text { 4.Content/ } \\
\text { Topic }\end{array}$ & $\begin{array}{l}\text { 5.Knowledge/ } \\
\text { Skills }\end{array}$ & $\begin{array}{l}\text { 6.Teaching } \\
\text { approach }\end{array}$ & $\begin{array}{l}\text { 11.Assessment/ } \\
\text { Evaluation }\end{array}$ \\
\hline & & & & & & \\
\hline & & & & & & $\ldots$ \\
\hline
\end{tabular}

Table 1 shows the elements that are normally used by teachers for instructional planning, in accordance with the national curriculum indications in force in Italy (MIUR, 2012), and namely: 1. context, considered in the broad sense and with reference also to pupils' characteristics; 2. goals for competence development and learning objectives; 3 . time that should be dedicated to the planned unit; 4 . disciplinary content or topic of the unit; 5. knowledge and skills that pupils should acquire or develop during the learning unit; 6. teaching approach or approaches that 
one intends to use, considering models, methods, formats, strategies and techniques; 11. tools for assessment and evaluation.

Table 2. New element for planning with integration of technology.

\begin{tabular}{|l|l|l|l|}
\hline 7.Technology & 8.Activity types & 9.Knowledge forms & $\begin{array}{l}\text { 10.Representation } \\
\text { modalities }\end{array}$ \\
\hline & & & \\
\hline & & & $\ldots$ \\
\hline
\end{tabular}

Table 2 contains the new elements that the students have studied from a theoretical point of view in the Educational Technology module. These elements have to be taken into consideration together with those in Table 1 . For point 7 , the students have to indicate in detail which technologies, both digital and nondigital, can be used. They are required to relate this point to points 4 and 6 in Table 1, bearing in mind the connections with content/topic and teaching approach, and consequently the constructs of PCK and TPACK. For point 8, activity types, they should specify each of the activities that pupils will carry out, in line with the theories of Harris and Hofer. The same theoretical reference is necessary also for point 9, knowledge forms, which should make it clear whether these activities are for knowledge building or knowledge expression, and, in the latter case, specifying of what kind. Finally, point 10 refers back to the theories of Cope and Kalantzis, and should include detailed explanations of the representation modalities that are implied.

To sum up, by using the combination of elements in Tables 1 and 2, the student teachers should develop an integrated planning procedure, structured on the following premises and questions:

- in a well-defined learning context with specific students;

- with well-defined goals for competence development and learning objectives;

- with a clearly-planned time schedule for the achievement of such objectives;

- within a field of experience or discipline area and a well-established content or topic, which it is believed can foster the acquisition and development of specific knowledge and skills;

a) which are the most suitable teaching approaches, technologies and activity types for dealing with such content and for developing such knowledge and skills, assuring that the learning experience be productive for the pupils?

b) which knowledge forms and representation modalities can be activated through the use of such approaches, technologies and activities?

c) which aspects of the learning experience is it useful or necessary to assess?

\section{Future developments}

At the moment this is a rather theoretical planning procedure which we started to use during the present academic year. We presented this planning instrument to the student teachers during the Educational Technology workshop which is due to be concluded at the end of January 2015. 
At the end of the workshop, the authors of this article intend to work closely with workshop tutors to examine the units planned by the student teachers and uploaded to the dedicated platform, gather their reflections on the planning and, presumably, carry out in-depth interviews with small groups of students (see Harris \& Hofer, 2011), in order to look more deeply into how they conceived the relationships between the various elements, how they passed from one to another and what were the difficulties they came across.

The ultimate aim is to develop an action research project that involves students and Primary Education Faculty to verify empirically the instrument we have outlined, about which some doubts still remain, among which whether we should consider the affordance of technologies as a further and entirely separate element (Angeli \& Valanides, 2013; Wang, 2008).

Our interest in defining a planning instrument that comprises the elements useful for an effective integration of technologies in teacher training, and in developing around it a suitable research project, goes well beyond any preoccupation about the organization of the Educational Technology workshop in itself and the general preparation of students in this field. Our ambition is wider and contemplates two separate aims: on the one hand to put students in a position to develop a framework in some way in line with the one suggested by Mishra and Koehler (2006) - which is at the same time procedural and dynamic, in such a way that it can be progressively refined and improved according to the knowledge domains that students will come into contact with during their training; on the other, to offer to university faculty of those disciplines to be nurtured in kindergarten and taught in primary schools a tool that could help them to provide more effective training in the integration of technologies in their specific disciplinary areas.

\section{References}

Angeli, C., \& Valanides, N. (2005). Preservice elementary teachers as information and communication technology designers: An instructional systems design model based on an expanded view of pedagogical content knowledge. Journal of Computer Assisted Learning, 21(4), 292-302.

Angeli, C., \& Valanides, N. (2009). Epistemological and methodological issues for the conceptualization, development, and assessment of ICT-TPCK: Advances in technological pedagogical content knowledge (TPCK). Computers and Education, 52(1), 154-168.

Angeli, C., \& Valanides, N. (2013). Technology mapping: An approach for developing technological pedagogical content knowledge. Journal of Educational Computing Research, 48(2), 199-221.

Archambault, L.M., \& Barnett, J.H. (2010). Revisiting Technological Pedagogical Content Knowledge: Exploring the TPACK framework. Computers \& Education, 55(4), 1656-1662.

Cope, B., \& Kalantzis, M. (Eds.) (2000). Multiliteracies: Literacy learning and the design of social futures. London: Routledge.

Cope, B., \& Kalantzis, M. (2009). "Multiliteracies”: New literacies, new learning. Pedagogies: An International Journal, 4(3), 164-195.

Cox, S., \& Grahm, C.R. (2009). Diagramming TPACK in practice: Using an elaborated model of the TPACK framework to analyze and depict teacher knowledge. TechTrends, 53(5), 60-69. 
Cullen, T. A., \& Greene, B. A. (2011). Preservice teachers' beliefs, attitudes, and motivation about technology integration. Journal of Educational Computing Research, 45(1), 29-47.

Enochson, A., \& Rizza, A. (2009). ICT in initial teacher education: Research review. OECD. Working paper n. 38.). Retrieved January 5, 2015, from http://www.oecd-ilibrary.org/education/ict-in-initial-teacher-training-researchreview_220502872611

Eurydice (2011). Cifre chiave sull'utilizzo delle TIC per l'apprendimento e l'innovazione nelle scuole in Europa. Retrieved January 5, 2015, from http://eacea.ec.europa.eu/education/eurydice/documents/key_data_series/129IT.p $\mathrm{df}$

Finger, G., Jamieson-Proctor, R., Cavanagh, R., Albion, P., Grimbeek, P., Bond, T., Fitzgerald, R., Romeo, G., \& Lloyd, M., (2013). Teaching teachers for the future (TTF) project TPACK survey: Summary of the key findings. Australian Educational Computing, 27(3), 13-25.

Grahm, C.R. (2011). Theoretical considerations for understanding technological pedagogical content knowledge (TPACK). Computers \& Education, 57(3), 19531960.

Harris, J., \& Hofer, M. (2009). Instructional planning activity types as vehicles for curriculum-based TPACK development. In C. D. Maddux (Ed.), Research highlights in technology and teacher education 2009 (pp. 99-108). Chesapeake, VA: Society for Information Technology in Teacher Education (SITE).

Harris, J. B., \& Hofer, M. J. (2011). Technological pedagogical content knowledge (TPACK) in action: A descriptive study of secondary teachers' curriculum-based, technology-related instructional planning. Journal of Research on Technology in Education, 43(3), 211-229.

Harris, J., Mishra, P., \& Koehler, M. (2009). Teachers’ technological pedagogical content knowledge and learning activity types: Curriculum-based technology integration reframed. Journal of Research on Technology in Education, 41(4), 393-416.

Hofer, M., \& Harris, J. (2010). Differentiating TPACK development: Using learning activity types with inservice and preservice teachers. In D. Gibson \& B. Dodge (Eds.), Proceedings of Society for Information Technology \& Teacher Education International Conference 2010 (pp. 3857-3864). Chesapeake, VA: AACE.

Kay, R. H. (2006). Evaluating strategies used to incorporate technology into preservice education: A Review of the literature. Journal of Research on Technology and Education, 38(4), 383-408.

Kay, R. H. (2008). Exploring the relationship between emotions and the acquisition of computer knowledge. Computers \& Education, 50(4), 1269-1283.

Kalantzis, M., \& Cope, B. (2012). Literacies. Cambridge: Cambridge University Press.

Koehler, M. J., \& Mishra, P. (2005). Teachers learning technology by design. Journal of Computing in Teacher Education, 21(3), 94-102.

Koehler, M. J., \& Mishra, P. (2008). Introducing TPCK. In AACTE Committee on Innovation and Technology (Ed.), The handbook of Technological Pedagogical Content Knowledge (TPCK) for Educators (pp. 3-29). Mahwah, NJ: Lawrence Erlbaum Associates.

Koehler, M.J, Mishra, P., \& Yahya, K. (2007). Tracing the development of teacher knowledge in a design seminar: Integrating content, pedagogy and technology. Computers \& Education, 49(3), 740-762. 
Lawless, K. A., \& Pellegrino, J. W. (2007). Professional development in integrating technology into teaching and learning: Knowns, unknowns, and ways to pursue better questions and answers. Review of Educational Research, 77(4), 575-614.

Messina, L., \& Tabone, S. (2011). Integrating technology into instructional practices: A training research-intervention with in-service teachers. REM-Research on Education and Media, 3(1), 142-163.

Messina, L., \& Tabone, S. (2012). Integrating technology into instructional practices focusing on teacher knowledge. Procedia: Social \& Behavioral Sciences, 46, 1015-1027.

Messina, L., \& Tabone, S. (2013). Technology proficiency, TPACK and beliefs about technology: A survey with primary school student teachers. REM-Research on Education and Media, 5(1),11-29.

Messina, L. \& Tabone, S. (2014). Technology in university teaching: An exploratory research into TPACK, proficiency, and beliefs of Education faculty. Cadmo, XXII(1), 89-110.

Mishra, P., \& Koehler, M. J. (2006). Technological pedagogical content knowledge: A framework for integrating technology in teacher knowledge. Teachers College Record, 108(6), 1017-1054.

MIUR-Ministero Istruzione, Università, Ricerca (2012). Indicazioni nazionali per il curricolo della scuola dell'infanzia e del primo ciclo di istruzione. Annali della Pubblica Istruzione, LXXXVIII. Special Issue.

Niess, M. L. (2005). Preparing teachers to teach science and mathematics with technology: Developing a Technology Pedagogical Content Knowledge. Teaching and Teacher Education, 21(5), 509-523.

Niess, M. L., Ronau, R. N., Shafer, K. G., Driskell, S. O., Harper S. R., Johnston, C., Browning, C., Özgün-Koca, S. A., \& Kersaint, G. (2009). Mathematics teacher TPACK standards and development model. Contemporary Issues in Technology and Teacher Education, 9(1), 4-24.

Pierson, M. E. (2001). Technology integration practices as a function of pedagogical expertise. Journal of Research on Computing in Education, 33(4), 413-429.

Rivoltella, P. C. (2012). Neurodidattica. Insegnare al cervello che apprende. Milano. Raffaello Cortina.

Shulman, L. S. (1986). Those who understand: Knowledge growth in teaching. Educational Researcher, 15(2), 4-14.

Shulman, L. S. (1987). Knowledge and teaching: Foundations of the new reform. Harvard Educational Review, 57(1), 1-22.

Tondeur, J., van Braak, J., Sang, G., Voogt, J., Fisser, P., \& Ottenbreit-Leftwich, A. (2012). Preparing pre-service teachers to integrate technology in education: A synthesis of qualitative evidence. Computers \& Education, 59(1), 134-144.

Voogt, J., Fisser, P., Pareja Roblin, N., Tondeur, J., \& van Braak, J. (2013). Technological pedagogical content knowledge - a review of the literature. Journal of Computer Assisted Learning, 29(2),109-121.

Wang, Q.Y. (2008). A generic model for guiding the integration of ICT into teaching and learning. Innovations in Education and Teaching International, 45(3), 411419. 